\title{
The Tradition of Melayokaken in Using Society: The Causal Factors and Its Impacts
}

\author{
Akhmad Haryono, Akhmad Sofyan, Samudji \\ Universitas Jember \\ Email: aharyono.sastra@unej.ac.id
}

\begin{abstract}
This article discusses the tradition of Melayokaken, the causal factors, and the impacts of the tradion on Using Society in Banyuwangi. Melayokaken, as a tradition of elopement, had been maintained by Using community for a long time. For some Using People in Banyuwangi (UPB), this tradition was regarded as a pride because it could help to maintain the tradition that had been formed since the time of their ancestors. But on the other hand, melayokaken tradition is considered violating the norms followed by Using people, namely religious norms, anti conflicts and living in peace. The method used in this study is qualitative method. Data were collected through participatory observations, interviews, notings, and recordings. The method of analysis used in this research is descriptive qualitative method. This research resulted in the finding that there is a factor that can maintain the tradition of melayokaken, namely as an alternative means to resolve the impasse communication in entering the marriage, for example due to: differences in status and social class, educational factors, the bride family may not marry more than one time in a year, the bridegroom candidate has not got a job yet, the candidates of the bride and the bridegroom are not yet old enough, the birth dates of the two are not good and matched, the marriage must not precede an older sister marriage, the bride candidate has already been betrothed by parents.

This entails two impacts of the tradition, namely positive and negative. The positive side proves that melayokaken can penetrate the gap in status and social class between the two families and the things which are recognized less rational in the contemporary perspective. And the negative side proves that melayokaken had violated the norms, ethics, and religious values embraced by Using society although there was no significant impact on the doers' social lives and in the community.
\end{abstract}

Keywords: anti conflict, Banyuwangi, elopment, impasse communication, Melayokaken, messenger, Using, Using community,

\section{INTRODUCTION}

Melayokaken, which means 'stealing or carrying away', is a wedding tradition of Using society in Banyuwangi. In this tradition usually an Using unmarried young man (UYM) carries away an Using young woman (UYW) he loved for not getting an approval from the UYW family. Melayokaken is a tradition that has been going on for ages. According to Saputra (2007) this tradition is actually a short cut to get into the marriage performed by a UYM who "steal" or carry his girlfriend away as their love affair is not approved by the parents.

Melayokaken is one example of the traditions prevailing in the community of $U P B$. This tradition is carried out when the UYW's parents disagree on the plan of the marriage proposed by the UYM she loved. In this case the young companion who has been in love actually have already been doing some furtive relationships. They both have been 
in the same intention, but when their desire was conveyed to the UYW's parents, they, in fact, do not get a positive response or blessing from the UYW's parents. Whereas the parents in the UYM's party have approved their relationship that has been pledged to the marriage.

The melayokaken tradition is an interesting phenomenon and quite important to be investigated and discussed. First, this tradition is a cultural asset that must be recorded in the domain of Indonesian culture aimed to understand the culture of a particular society that becomes the uniqueness of Indonesian culture; second, this finding can be used as a solution between the doers and families to fulfill the desire to build the smallest and sacred institution of the so called household, without sacrificing the values of noble culture that have been becoming the convention in Using society. Those are harmonious, ethical, mutual cooperation, and religious.

Using culture rooted in the traditional agrarian basis value with slametan (ceremonial meal) as a projection of the values of harmony (which is also the expression form of harmonization of microcosm and macrocosm world relations) that also reflects the cultural characteristics of Javanese culture in general (Saputra, 2007). Hence, Using culture actually does not confirm the presence of a tradition that can cause conflicts between families in the Using society.

Based on those reasons, the research problems are formulated as follows. What are in fact the causal factors of the tradition of Melayokaken, and what are the impacts of melayokaken towards the doers, i.e., the $U \mathrm{YM}$ and the $U \mathrm{YW}$, and their social lives in the community?

The method used in this research is descriptive qualitative method. According to Bogdan and Taylor (1975), a qualitative approach is a research procedure that produces descriptive data in the form of written or spoken data of people and behaviors that can be observed. Data were collected through participatory observation, interview, note-taking and recording. The method of analyzing data used in this research is descriptive qualitative method.

The locations used in the implementation of this study are within the scope of Banyuwangi district which is actually inhabited by Using people where the tradition of melayokaken are still frequenly common.

The data were obtained from three sources: the first (primary) were excavated from direct observation through participation observation and interviews with the actors of melayokaken; the second (secondary) were obtained from parents of perpetrators who are often involved in the conspiracy of melayokaken tradition; and the third were in the form of information from religious leaders and scientists who pursue studies in cultural anthropology and Using people.

All the data above were collected through participatory observation, interviews, recording and noting. The data that has been gathered and collected then classified and subsequently interpreted in the form of descriptive qualitative analysis. This kind of analysis models will be presented and analyzed in greater detail and depth to meet the question in the research problems.

\section{MARRIAGE AS A FINAL GOAL OF MELAYOKAKEN}

The word marriage is no longer odd in the mind of normal human being in both physiological and psychological point of view. Every day even almost every time, this word is often heard or read either through the media or invitation coming from relatives, friends, colleagues and those who involves us in a wedding party. However, when it is questioned what is meant by the term marriage or among Muslim it is often also known as pernikahan (wedding), then whosoever will think bit longer to get the fit definition of that word, even though what is meant by that term has been obviously in the mind. Therefore, before commencing in depth discussion of this issue it is necessary to revisit the term/ definition of the word marriage as the final goal of melayokaken tradition.

Marriage is a transaction and a legal and official contract between a woman and a man that affirm their rights to have a sex with each other and attests that the woman has been able to deliver a baby (Haviland: 1993, Haryono: 2008). According to (Hornby, 1957, Walgito 2002, Haryono, 2008) Marriage: the union of two persons as husband and wife. Based on the Marriage Act No. 1 Year 
1974: marriage is a physical and mental bond between a man and a woman as husband and wife aiming to build a happy and eternal family (household) based on the One God.

For Javanese, marriage is an important step in the process of human integration in the system of nature. It must meet all the requirements set by tradition to go into the sacred system of nature (holy). The marriage ceremony is not only the process of leaving the old life to go to the new one, but rather an assertion and a renewal of the whole system of nature of the entire society. (Haryono, 2008)

Marriage is one of the individual activities which has been combined into one unity so called family. Individual activities or family generally relate to one goal that is achieved by the individual or family. So it is as in a marriage. As marriage is the activity of a pair, so it is necessary for them to have a specific purpose, but as it consists of two individuals, so there is possibility that their purpose is not the same. If that happens, then the goal should be unified so that there is one similar purpose (Walgito, 2002). Therefore, to begin a new life preceded by marriage, adaptation to share the same perception of marriage purpose is an extremely important point to do, so that the physical and mental bond reflected in the understanding and the definition of marriage actually can be realized in the family life.

In a marriage, there occurs a physical and mental bond between a man and a woman as husband and wife. Thus it is obvious what are bounded in a marriage as husband and wife are a man and a woman. It also means that if there are two men and two women are bounded as husband and wife through marriage, then based on the marriage act in Indonesia, this is clearly cannot be implemented. It is unlike western countries whose laws authorize a marriage between man and man and woman with woman. They can be tied up into a spouse, even though they are in the same sex.

In a marriage there must be two bonds, those are physical bond and mental bond. The physical bond is a visible bond for both families or in society or a formal bond based on legislation and customs that has been becoming a particular community convention. This physical bond (formal) binds both of them (husband and wife) as well as the man and woman's big family and the wider community. Therefore, a marriage generally is informed to the large community so that people know that two beings are legal as husband and wife through marriage. The way to inform the marriage is varied depending on the condition and customs in the society and also the desires of both families, such as through wedding party that invites the people, relatives, and friends or by advertising through mass media. The mental bond is an invisible bond and it is merely a psychological bond between husband and wife, it means that they must love each other, and no force from any people in a marriage. If there is a force in a marriage, not based on compassion, so then it means that there is no mental bond in a marriage. Therefore, those two bonds in a marriage are a prerequisite in creating a happy family (quiet). If one is absence, so the marriage will face any problems in sailing an ark of life.

In the tradition of Using society in Banyuwangi, it does not recognize the disharmony in a household although at the beginning they do not get the parents' blessing. It is due to the bridal party will feel ashamed after forcing the parents for her life partner. The bridegroom will be more responsible to work for his wife and children later, so then in Using society the divorce rate is very rare or even almost none. Their motto is "Sabok ejo kesiluran, ora nemu jodho tetep seduluran" which means "although being unable to find a mate, brotherhood remains going on'. Hence, the relationship in a household as well as with the failed parent-in-law still remains good. (Interview with Mr. Niptah, 65 years old. The Kemiren resident whose the marriage is processed through melayokaken).

That data confirms that melayokaken has a positive side as this can deliver the bride and groom into the happy and prosperous life ark as the marriage in common. The life of household that tries to avoid conflict and divorce is as the form of responsibility of those partners even at first their marriage is passed through the willing force to the parents through melayokaken way. 


\section{'MELAYOKAKEN' AS A TYPICAL TRADITION OF USING PEOPLE IN BANYUWANGI (UPB)}

In Using society, the man party does not want to speculate proposing a girl if there is no the green light (approval) from both parents of the woman and her big family. As the consequence, the melayokaken tradition is performed.

As what has been told by the informant that melayokaken has another term 'colong' in Javanese, which means 'steal' in Indonesian language. It is due to the man carries the woman away without being known by woman's parents. Melayokaken generally occurs as the man do not get the approval from the woman's family (Interview with Mr. Salihin, 35 years old, Head of Krajan, Rejosari Village, Glagah District, Banyuwangi Regency).

In a normal situation, the intensive communication is done by the woman with the man through 'jaruman' (matchmaker). As the result, it is then communicated with the man's parents. If the green light is there, so the normally proposal preparation is held. Yet it is rejected for some reasons, even though both of them do really want to live together legally as they fall in dead love. The young man will be dared, whether he is serious to propose the the girl. As it is yes, does he dare to do 'Melayokaken' (carry away) the girl from her parents to be brought into the man's family home.

The action of 'melayokaken' is usually undergoing enough preparation in order to avoid misunderstanding between families. In addition to the woman's will, it can be assured that this action also has gained the support from some of the woman's family who disagree with the attitude of her parents. Then, the next plan is determining the right time for the man to carry the woman to be placed in the man's family. Everything has been set by parties involved in melayoaken action. Especially for man's family, they have set the strategy and decide who will be involved in this process. Either as a protector when the girl has arrived, or a person becoming a 'colok' (mouth), or as messengers to the woman's parents.

However, there is also the action of melayokaken which is not planned before either by the man's family or the woman's family, they who know are only the young man and woman as it has been experienced by Adi and Tinah (not the real name) residents of Olesari. They plan this on their own both of the families do not yet know about their two children who are escaping. Adi carried Tinah away to one figure's house who is used to being 'colok' and he happens to be a friend of the man's brother. This action is performed as Adi is afraid of his brother since his father passed away, he is responsible to the family. After being told by the figure about what was going on to his brother who had carried away a woman, the brother was quite upset, it is not because his brother had fled the girl but due to he carried her into someone else's house. Once after returning to the man's house, the 'colok' was appointed to come to the woman's house to tell them that their daughter was safe at man's house.

Adi as an immature man who still do not know the good days for performing melayokaken, it is coincidentally the unlucky day based on the calculation of Using people. Therefore, before it is known that the woman was stolen, she must be returned to her home to wait for a good day. If the parents ask about her daughter coming home late then as the common reason is staying at friend's home. Once after the good day is determined by the leader of Using or the shaman then melayokaken is repeated.

For the woman's parents, the incident of melayokaken feels like they get a disaster 'kepetengen' (Darkness) when losing their daughter. Therefore, there is someone who is delegated to 'enlighten' (colok) the woman's family. A plug 'colok' a person who have a good communication skill and argumentation. He is usually a figure of local society who is powerful so that his presence does not cause the anger or conflict from the woman's party. This colok comes to woman's family and he usually says that the daughter has been carried away by a young man who becomes her choice but the relationship is not approved. Colok also convinces the woman's parents that their daughter is alright. Her heart is glad, as she is well accepted by the man's family.

Uniquely, the woman's parents would not be angry and do not reject the proposal with the way 
of di-playokaken (being carried away). It is due to, for Using society, it will be a disgrace if the plan to hinder their children's love relationship is known by others. The greatness of this step of melayokaken is also effective to break in the social classes in Using society even the man or woman is in different social status. Se-wangkot (as very upset) the parents' heart will melt after knowing her daughter is carried away by the young man. This attitude is sometimes also because of the 'colok' expertise in communicating with the woman's parents. The woman's parents probably will also be embarrassed to the 'colok' as he is a figure of local society.

If the agreement is there, so in that night the 'colok' will carry the woman's parents to see the men's family (candidate of marriage family relationship) and at the same time want to know their daughter condition. At this sudden meeting, then the formal wedding plan is arranged, the calculation of date and weton is still convinced by the Using people to conduct the wedding party. Even, the realization is not as strict as the Javanese that must calculate the date of birth and the market and is summed totally.

So far, the tradition of 'melayokaken' has never ended into the law domain. For example, the woman's parents report to the police as their daughter was taken away by young man without the permission of the woman's parents. However, in the tradition of melayokaken there are some conditions that must be fulfilled, that is the man's party must immediately send the 'colok' for at least less than one times 24 hours. Even sometimes parents or the woman's party have just realized or known that their daughter is under the man's power, when a colok comes to them. Here is what is possible, the tradition that seems to be contrast to the positive law but it never ends to legal table.

As it has been told by Nadiri aged 55 years old, a religious figure in Banyuwangi stated that when the colok has come, so then the problem is over. The woman's family then is back to the destiny by saying 'what else could we do? $\mathrm{He}$ is probably her soul mate'. Besides, there are more relatives and neighbors who ngedem-ngedem (cooling down the atmosphere) to accept the already happened conditions by saying 'what can we say? Age, mate, and livelihood Allah decides.'
This is in line with the traditions and the basic values of traditional agricultural with slametan (ceremonial meal) as a projection of the value of the harmony (which also the form of expression of harmonization as the implementation of the norms adopted by Using society elaborated as religious, harmonious and conflict avoidance.

This tradition, sometimes it is called as 'kawin colongan' (stealth marriage). This term is actually sourced to a living tradition in Bali. If it is used to denote the tradition that lives in Banyuwangi, the term was inappropriate. Remembering that the normal marriage procession is as conducted as usual. The problem of dead locked communication has been over after the coming of colok. The woman's parents quickly do self-introspection when the daughter is taken away by the young man and do not force their willing instead.

'Ngeleboni' (return) has a similar character with the tradition of 'melayokaken'. This tradition also reflects the courage of Using young man to behave or realize if his desire to propose the adorable woman do not get her parents' approval. The young man with the help of his 'team' that agrees his way to 'ngeloboni' to the woman's parents (the woman's party).

At the time of ngeleboni, the young man usually has already known the response of the man's parents on their relationship. In order the parents watch his seriousness then the young man directly go facing the woman's parents and propose her as his potential companion. In another side, the woman's parents do not easily accept the man's proposal, they still require him to go with his parents or delegations who accompany him.

It is not way different from the process of 'melayokaken', the existence of 'colok' is also required in this tradition. They will come to the man's parents and tell them if his son is now doing 'ngeloboni' to the daughter of Mr. Paimin for instance, who is merely his own girlfriend which this relationship is not approved by the man's parents. Again, for Using people it is a disgrace, if the desire that hinders the love relationship is widely known. This can be predicted that the approval will be obtained. The process of arranging the wedd ing day is immediately conducted. It is usually will not be long, as they fear that sacred relationship turns to be sin due to the too long 
wedding day.

In under normal conditions, that both parties equally give the approval, in Using society it is called as 'bakalan' process (engagement/ proposal). Usually the man's party who proposes the woman by bringing 'peningset' (binder from gold, and a complete set of clothing) and also some souvenirs such as: cakes, fruits, and other foods. Later in the due day, there will be a reciprocal visit from the woman's family. Commonly the woman's party brings any dishes, cakes, fruits and so on as souvenirs decorated with interesting ornaments.

Nevertheless, Using people also cannot guarantee that the process of 'bakalan' can be really going on until the wedding day, if it is not soon conducted. The two parties are also reminded that 'bakalan' is the human plan. If there is a hindrance or obstacle on the middle way, both sides are asked not to blame each other. It is as reflected in the Using basanan or rhyme: Ojo maning singkal ro kuthungo, Sasak Watu bainembatan embat would be ro // Ojo maning bakal ro wurungo, wis anak putu bain bisa pegatan. (Instead of the rover will not be broken, Bridge of stone could be swayed. Instead of the engagement will not be canceled, people who already have great grandson could divorce).

\section{CAUSAL FACTORS OF THE PERSISTENCE OF MELAYOKAKEN TRADITION}

Every ethnic tradition definitely has two sides that interrelates each other, those are the positive side and the negative side. The positive one, as a normal marriage should be (that has got an approval from both parties), melayokaken also aims to build a household through a legal marriage and the woman is also treated well and kept her purity. And more than that, melayokaken can break through the gap of class and social status in society that mostly becomes the reason for not giving a blessing to a couple who is falling in love. Through the tradition of melayokaken, the couple who is not blessed before because of status and social class will be falling over on its own. The negative side is melayokaken has broken the norms followed by Using society such as religious, harmonious, and conflict avoidance since melayokaken has initiated a sacred purpose and conflict between families and even it embarrasses the woman's family and has violated the rules of the religion embraced by UPB.

With those sorts of norms, the Using culture definitely would not justify any adverse actions or even cause a conflict with other parties. Considering the function of culture as norms to behave regularly (Haviland, 1988: 223), the culture of a society will never justify any adverse actions and injure the honor of others. That proposition indicates that the Using culture which is conducted appropriately will create the good attitude and behavior of Using people and will not bother others' rights. Here are some factors that can influence the persistence of melayokaken tradition.

\section{Being the Alternative Way of Communication Deadlock in A Marriage}

Culture can be recognized as the result of human activities in its relation to the life, work, time, nature, and the human itself, (Kuntjaraningrat, 1987, Haryono, 2008). Furthermore, Marzali (2014) stated that culture is the power or capability of the intellectual, emotional, and spiritual elements from a social group that aims to raise the human dignity of the social group. Marriage is a part of the culture that cannot be separated from the intellectual, emotional, and spiritual elements which has become a convention in a particular community environment both related to the steps and the implementation.

Melayokaken which is merely one initial way of UPB marriage has been becoming a tradition for a long time. Even this tradition is their ancestors' heritage. As a civilized community, of course, that tradition must be based on the norms embraced by UPB realized in the desire to build a household on the basis of loving each other without any block of status and social class. Therefore, up to now melayokaken still becomes an alternative way to go through the marriage when the communication between man's family and the woman's is in the deadlock.

\section{Educational Factor}

The educational level of the parents and the doers is one factor that also determines the persistence of melayokaken as this tradition commonly occurs to the young man and woman who have relatively low education. Like the parents involved in a conspiracy of melayokaken 
usually they who are in the middle-low educational level. This is reflected in the informants who are involved in the group of doer or as the parents who are mostly the graduate of elementary school and senior high school only.

According to the informants' information who have relatively higher education, in general, they start to consider that melayokaken is no longer appropriate to do at this time. Most of them feel embarrassed with the marriage that is realized through the means of melayokaken. They think that the parents nowadays are accustomed to have a discussion with their children about the choice and the marriage that will be held. They also argue that melayokaken has violated the norms, ethics and religious values embraced by the society. Nevertheless, they also do not blame if some of Using people still persist melayokaken as a way to get into the ark of household. As the result, melayokaken has been becoming a long-lasting tradition and a pride for some Using people.

\section{Status and Social Classes Gap}

The gap in status and social classes between the man's family and and women's is the early cause of melayokaken. Every parents definitely want their children to have a better life. The status and social classes that is relatively the same is predicted to be able to realize the purpose of having a happy and wealthy life. That is the opinion for most Using people so that they prefer to retain their children to marry someone based on the parents' criteria and desire, even sometimes the candidate is chosen by the parents. Therefore, the parents are often put in dilemma and difficult choices in bringing their children to the marriage. On the other hand, there is the settled man with similar status and social class has proposed their daughter, yet her daughter does not love the man. In another side, a man with different social class also wants to realize his intention to propose the woman, but he is not blessed by the parents. This what makes their daughter with her lover and his family try to madke a conspiracy to do melayokaken.

\section{Less One Year Marriage in Women's Family}

According to UPB, the woman's family, in one year, is not allowed to marry her daughter twice or more. It is considered taboos in the tradition Using community. Therefore, if both man and woman of Using want to hold the marriage very soon so then they plan to do melayokaken as the result the marriage can be conducted in the man's house. If it is contemplated rationally to hold the wedding twice in one year is very bothering and displeasing in both the aspect of cost and energy. Further, this must bother the neighbors and the big family as it is unlikely if one of the family member in Using society has the agenda such as the wedding would not involve the people in surrounding. This is what actually originates the reasons that cause the woman's family feel displeased and also embarrassed to hold the wedding party more than once in a year.

\section{Unemployed Husband to be}

The refusal coming from woman's party can also be due to the bridegroom to be does not have a proper job. For most Using people, a husband is one of the pillars that can balance the family economy so that it is expected to trigger the family's prosperity which has an impact in the household harmony. Hence, the job aspect of a potential husband is often becoming the main reason for the rejection from woman's party that eventually becomes the motive of doing melayokaken.

\section{Immature Age}

Age is the main requirement in getting into the stage of marriage. Department of Religion in the Marriage Act states assertively that in the marriage the man must be 19 years old, while woman must be 16 years old. As it is considered that when the young woman 16 years and the man in 19 years old conduct the marriage, generally the spouse has been able to produce the descent, if there is no factor that hampers it. Thus, once again it can be emphasized that the age limitation is given more attention on the physiological aspects (Walgito, 2002; Haryono, 2008). For those reasons, there are many elderly particularly Using people who do not approve if their immature daughter is proposed also by immature man. As the road to get into their marriage, they use a shortcut by doing melayokaken. 


\section{Bad Weton (Unmatched Dates of Birth)}

Weton is Javanese almanac calculation consisting a combination of seven days in a week (Monday, Tuesday, etc.) with five days of Javanese market (Legi, Pahing, Pon, Wage, Kliwon). According to Javanese belief, the meaning of an event (and the character of a person who is born in a particular day) can be determined by examining the time of the happening based on any sorts of traditional calendar rotation. One of the common use from these prediction methods can be found in the system of the Javanese birth so called wetonan. Weton is also used by Using community for many things including to determine matchmaking. When a man is going to propose a woman, then what is done by the woman's party is asking his weton and later it is consulted to the Using leader or the shaman who is convinced to have a good expertise in calculating weton. If the calculation result of the man's weton the woman's is not good, then the marriage proposal will be rejected by the woman's family - there are some who are so fanatic towards the weton calculation of the man's family or both. This what triggers the woman and the young man to conspire in doing melayokaken or nglebone.

\section{The woman is not allowed to marry before her older sister}

For Using people, it is considered taboo for woman to precede her older sister's marriage. It aims to keep the sister's feeling so then she does not feel embarrassed to the society. Thus, if the woman's older sister has not got married, the parents will not accept any marriage proposal for their younger sister spoken. As a way out to fasten the marriage so these two humans who love each other conspire to do melayokaken.

\section{The woman is engaged with the man selected by her parents}

Two youngsters who love each other often find some problems as they are going to go into the marriage level, such as the parents have matched their daughter or son with a man or another woman who they think can bring a happier live. This phenomenon occurs in any ethnic including Using people. The disappointment of these two beings who love each other is becoming a main reason to take a shortcut by doing melayokkaken.

\section{THE IMPACT OF MELAYOKAKEN ON A SOCIAL LIFE OF UPB COMMUNITY}

The spouse as the result of marriage conducted through the process of melayokaken is treated equally among Using society since it has been becoming a customary tradition for the marriage and it is good and legal either based on the government law or religion. For the next, they become exist or not in the society depending on their attitude and behavior to adjust themselves to the surroundings as a new family supposed to be. It accords with the statement of Pingkan (2011) that the early phase of marriage is an adjustment period that is difficult for a spouse. Therefore, the adjustment in this period is really important for marriage quality next in the future. Hence, the future success of the couple depends on their ability to adapt both in the family and in society.

In the economic side, the couple through the process of melayokaken depends on their attempt after conducting a marriage. In general, they work hard just to show the woman's parents that he is a responsible man with their daughter whom he carries away (pelayokaken). Nevertheless, as seen from the background which is mostly not coming from a high education, it is definitely luckier for them who have a better educational background in finding a job.

The couple as the result of the process melayokaken generally keep their harmonius life to show the parents who are forced to give a blessing due to being carried away (dipelayokaken). They feel embarassed if the marriage must be ended with the divorce. However, everything depends on the couple for their household life journey, there who are successful to keep it, but there is a little amount who are not successful to keep the harmony so then it must be ended with the divorce. Thus, this can be said that the household harmony for the doer of melayokaken is not way different from the marriage that undergoes the proposal process which gets the parents' blessing from the beginning- just for that und ergoes the process of melayokaken requires more efforts to keep it as in the beginning there is a force to the parents. 


\section{CONCLUSION}

Melayokaken is one of the eloped marriage tradition in UPB that still becomes one of the way to get into the legal marriage level. The tradition is still performed by UPB for some factors: Factor of tradition that has been a custom for a long time, there are two parties who love each other but do not get the blessing from the parents due to status and social class of two families are different, woman's family party is not allowed to hold the marriage twice within a year, the woman's older sister has not yet got married (younger sister cannot precede), both of the man and woman are still immature, he/ she is engaged with another man or woman, and other factors, and also factor of society's education is still at the middle-low category.

There are two positive and negative sides as the impact of melayokaken. The positive one is that melayokaken can break through the gap in status and social class between two families in a community and local beliefs are not in accordance with the Islamic religionn addhered by Using community. The negative one is melayokaken has violated the norms, ethics, and religions embraced by Using community. However, it does not impact on the social life and the harmony either in the family or society where largely Using Muslims are living in harmony, and loving to work together as the findings of previous studies have stated.

The impact of melayokaken or nglebone to the social life and the household harmony is not way different from the normal marriage (through the proposal process and engagement). All problems of melayokaken are considered over with the coming of colok either as man's family delegation (in melayokaken) or the woman's (in ngelebone). Hence, social sanction, economy, and household harmony function normally depending on the development of the couple after conducting the marriage. This is in a row with the opinion of rel igion leaders, community leaders, and Using cultural observers that melayokaken has become a common tradition for Using society and been understood by community so that melayokaken or ngeleboni is never be a legal case.

Thanks to DITLITABMAS who supports us by giving research fund in order to complete the research. We hope that this research can be continued based on the roadmap.

\section{REFERENCES}

Darusuprapta. (1984). Babad Blambangan. (Unpublished Dissertation). Universitas Gadjah Mada, Yogyakarta

Greetz, C. (1973). The Interpretation of Culture. New York: Basic Book Inc. Publishers

Haryono, Akhmad. (2008). “Tradisi Perkawinan Usia Dini Etnis Madura di Jember. Jurnal Kultur Vol.2 No.1 Maret 2008. Jember: Puslit Budaya Jawa dan Madura Lemlit Universitas Jember.

Hasan Ali Sentot. (1995). Basanan dan Wangsalan sebagai Kritik Sosial: Tinjauan Awal terhadap Sastra Lisan di Banyuwangi". Warta ATL: Jurnal Pengetahuan dan Komunikasi Peneliti dan Pemerhati Tradsi Lisan. Vol. 1 No. 1. hlm. 45-50.

Haviland, William, A. (1993). Anthropologi, diterjemahkan oleh R.G. Soekadijo. Jakarta: Erlangga.

Hornby, A.A.S. Gatenby, ME.V.,Wakevield,M. (1957). The Advanced Learner's: Dictionary of Current English, London: University Press.

Koentjaraningrat. (1987).Kebudayaan Mentalitas dan Pembangunan. Jakarta: P.T Gramedia.

Marzali, A. (2014)."Memajukan Kebudayaan Nasional Ind onesia" dalam Humaniora, Volume 26, Nomor 03, Oktober 2014. hal 251-265. Yogyakarta: FIB UGM.

Peraturan Pemerintah Republik Indonesia Nomor 9 tahun 1975, Tentang Pelaksanaan UndangUndang Nomor 1 tahun 1974 Tentang Perkawinan.

Pingkan, C. B. Rumondor. (2011)."Gambaran Penyesuaian Diadik pada Pasangan Dewasa Muda di Awal Pernikahan"dalam Humaniora, Volume 02, Nomor 01, April 2011. hal 468476. Yogyakarta: FIB UGM.

Saputra, H. S.P. (2007). Memuja Mantra Sabuk Mangir dan Jaran Goyang Masyarakat Suku Using Banyuwangi. Yogyakarta: LKiS

Undang-undang Republik Indonesia Nomor 1, tahun 1974, Tentang "Perkawinan".

Walgito, Bimo, (2002). Bimbingan dan Konseling Perkawinan. Yogyakarta: Andi Offset. 